\title{
Türk Mali Tarihinde Varlık Vergisi Uygulaması ve Sosyo-Ekonomik Sonuçlarının Değerlendirilmesi
}

\author{
DOI: $10.26466 /$ opus.735644
}

*

\author{
Mutlu Yoruldu * \\ * Dr. Öğr. Üyesi, Balıkesir Üniversitesi, İktisadi ve İdari Bilimler Fakültesi, Balıkesir/Türkiye \\ E-Posta: mutlu.yoruldu@balikesir.edu.tr \\ ORCID: $\underline{0000-0002-1010-2938}$ \\ Öz
}

Dünya'nın mali tarihine bakıldı̆̆ı̆nda, ortaya çıkan olağanüstü dönemlerin siyasi, sosyal, ekonomik ve kültürel alanlar başta olmak üzere pek çok alan üzerinde olumlu veya olumsuz etkilerinin ve yansımalarının olduğu görülmektedir. Söz konusu olağanüstü dönemler deprem, sel, salgin, kasirga gibi doğal afetlerin neticesiyle oluşabilecekleri gibi ülkeler arasında yaşanan savaş ve çatışma hallerinin bir sonucu olarak da doğabilmektedirler. Kamu maliyesi açısından olağanüstü dönemlerin meydana getirmiş olduğu önemli sonuçlardan biri ülkelerin vergi sistemleri ve mevzuatlarında gerçekleşebilmektedir. Böylesine dönemlerden geçen veya bu dönemlerden etkilenen ülkelerde devletler; vatandaşlarından ek bir vergi almayı kendileri açısından meşru görebilmektedirler. Olă̆anüstü dönemlerin piyasaları yıkıcı ve bozucu etkilerini telafi edebilmek için devletlerin eliyle birtakım harcamaların yapılmasının gerekliliği muhakkaktır. Bu gerçeklikten hareketle devletler vergi sistemlerine ya yeni bir vergi ekleyerek ya da mevcut sistemde var olan vergilerin tabanım genişleterek, oranların veya miktarlarını arttırarak finansman açıklarını temin etmeye çalışabilmektedirler. II. Dünya Savaşı'nın devam ettiği olağanüstü dönemde, Türk mali tarihinde uygulanmış olan 1942 yılında getirilen "varlık vergisi" bu tür vergilerin bir örneğini oluşturmuştur. Bu çalışmanın amacl; Türk mali tarihinde önemli bir yere sahip olan "varlık vergisi"nin sosyo-ekonomik sonuçların ortaya koymak ve tartışmaktır. Bu amaca ulaşmak için nitel araştırma yöntemlerinden biri olan betimsel analiz ve doküman taraması tekniğinden yararlanılmıştır.

Anahtar Kelimeler: Olağanüstü Vergiler, Varlık Vergisi, Sosyo-Ekonomik Sonuçları 


\title{
Application of Assets Tax in Turkish Financial History and Evaluation of Socio-Economic Results
}

\begin{abstract}
When reviewing the financial history of the world, one can see that the extraordinary periods had positive or negative effects and reflections on many fields, particularly on political, social, economic and cultural fields. These extraordinary periods may occur because of natural disasters such as earthquakes, floods, epidemics, hurricanes as well as of war and conflicts between countries. One of the important results of extraordinary periods in terms of public finance is the changes in the tax systems and regulations of the countries. In countries that are experiencing such periods or that are being/have been affected by such periods, governments may find it legitimate to impose an additional tax on individuals in the community. It is obvious that governments have to make certain spending in order to compensate for the destructive and disruptive effects of extraordinary periods on markets. Based on this reality, governments can try to close their finance deficits by either adding a new tax to their tax systems or expanding the base, increasing the rates or amounts of the existing taxes in the current system. The "wealth tax" in Turkish public finance history, which was put into force in 1942 in the extraordinary period of World War II is an example of such taxes. The purpose of this study is to reveal and discuss the socio-economic consequences of the "wealth tax", which has an important place in Turkish financial history. Descriptive analysis technique, which is one of the qualitative research methods, and document scanning technique were used.
\end{abstract}

Keywords: Extraordinary Taxes, Wealth Tax, Socio-economic results 


\section{Giriş}

İnsanlık tarihi boyunca insanoğlu birçok olağanüstü dönemden geçmiştir. Bu olağanüstü dönemlerin bir kısmının kaynağında deprem, sel, salgın gibi doğal afetler bulunurken, bir kısmının kaynağında ise ülkeler arası yaşanan savaş ve çatışma halleri ile ekonomik krizler bulunmaktadır. Bu dönemlerin birçok alana ilişkin yine birçok etki ve sonucu oluşmaktadır. Siyasi, ekonomik, sosyal ve kültürel alanlar başta olmak üzere hemen hemen her alanda etki ve sonuçların görülmesi muhtemeldir. Genelde küresel çapta etki gösterip sonuçlar doğururken, bazen de etkisi ve sonuçları daha sınırlı olağanüstü olaylar da yaşanabilmektedir. Olağanüstü olayların etkilerinin görüldüğü toplumlarda ekonomi politikalarının telafi edici bir rol üstlenmesi ve piyasaları devlet müdahalesinin olması kaçınılmazdır. Nihayetinde ortada olumsuz sonuçlara neden olan ve kamu idaresinin daha fazla mali politikalar uygulayarak piyasada aktif bir pozisyon almasın gerekli kılan bir durum bulunmaktadır. Böyle dönemlerde piyasanın bozulması ve finansman sıkıntısı yaşaması, devletin harcamalarını arttırması ve dolayısıyla artan harcamaların ek finansman tedbirleriyle karşılanması zorunluluğu ortaya çıkabilmektedir. Olağanüstü dönemlerde devletlerin yeni bir vergi koymaları veya mevcut vergileri arttırmaları meşru görülebilmektedir. Bu meşruiyeti veren ise devletin piyasada aktif rol alması zorunluluğu karşısında ortaya çkan finansman ihtiyacıdır. Aynı zamanda ilgili dönemlerde yeni vergilere karşı halkın reaksiyonunun topyekün başa çıkma anlayışı gereği daha sınırl kalacağı düşünülebilmektedir. Türk mali tarihine bakıldığında II. Dünya Savaşı'nın başladığı 1939 yılından sonra hem finansman ihtiyacını karşılamak hem de vergilendirmenin mali olmayan amaçlarına ulaşabilmek için 1942 yılında "varlık vergisi" getirilmiştir. Varlık vergisi bir servet vergisi niteliğine sahip olmuştur. Toplumun serveti üzerinden devlete belli ölçülerde kaynak aktarımının sağlanması amaçlanmıştır. Ve böylelikle savaşın olumsuz etkileri telafi edilmek istenmiştir. Fakat verginin getiriliş amacı meşru olarak ifade edilebilirse de; uygulamada yaşanan olumsuzluklar ve verginin adalet ve genellik ilkeleri ile çelişkili davranışlar birtakım sosyo-ekonomik sonuçların doğmasına neden olmuştur. Bu çalışmada 1944 yılına kadar uygulamada kalan varlık vergisinin kapsamı, amaçları, uygulanma şekli ve tartışmalara neden olan sosyo-ekonomik sonuçları üzerinde durulmuştur. Türk mali tarihindeki önemine istinaden çalışmanın literatüre katkı sunacağı değerlendirilmiştir. 


\section{Varlık Vergisi ve Uygulaması}

Dünya' da geçmişten günümüze ve içinde bulunduğu ekonomik örgütlenmelerden bağımsız olarak servet üzerinden alınan vergiler, ulusal vergi sistemlerinin en önemli kaynak alanlarından birini oluşturmaktadır. OECD ülkeleri nde son 10 yıllık süreç mercek altına alındığında, ülkelerin ulusal vergi sistemlerinde servet vergilerinin önemli ölçüde artış eğiliminde olduğu görülmektedir (Drometer, Frank, vd., 2018, s.47). Gelişmekte olan ülkeler baz alındığında gelir ve servet üzerinden alınan vergilerin, ülkelerin vergi sistemleri içinde önemli bir paya sahip olmadıkları saptanabilmektedir (Thaçi ve Gerxhaliu, 2018, s.214).

Varlık vergisi; kısa bir süre için Türk Vergi Sistemi içinde yer almış olmasına rağmen etkileri ve sonuçları itibariyle iz bırakan bir vergi olmuştur. Varlık verginin bir vergi olarak ortaya konulması birçok gerekçeye bağlanmış, uzun uzun tartışılmış ve kanun olarak hazırlık aşamaları tamamlanmıştır. Verginin kanun olarak hazırlanış şekli ve içeriğinden daha çok uygulamada yaşanan sıkıntılar, verginin sosyo-ekonomik sonuçları üzerinde tesirli olmuştur.

\section{Varlık Vergisinin Ortaya Çıkışı}

Dünya'da 1900'lü yılların başları itibariyle "ulus devlet" anlayışı hâkim olmaya başlamış ve çok uluslu devletler dağılarak yerlerini ulus devletlere b1rakmaya başlamışlardır. Bunu hem bir nedeni hem bir sonucu olarak da azınlık haklarının korunması ve genişletilmesi bütün dünya devletlerinin temel sorunlarından biri haline gelmiştir. Osmanlı İmparatorluğu da gayrimüslimleri temsil eden çok uluslu bir toplum yapısına sahip olduğundan, İmparatorluğu'n dağılması ile birlikte aynı toplumsal yap1 29 Ekim 1923'te kurulan "Türkiye Cumhuriyeti Devleti" ne devrolunmuştur. Azınlıklar olarak ifade edilen bu kesim, daha çok ülkede ticaret ile iştigal olmakta ve üretim faktörlerinden sermayeyi daha çok ellerinde bulundurmaktadırlar. Kısacası ulus devletlerin önemli faktörlerinden olan burjuva sinıfı, Türkiye'de Gayri Müslim olan bu azınlık kesimden oluşmaktadır (Lewis, 1998, s. 22). 
Düşman işgalinden verilen topyekün bağımsızlık mücadelesi sonucu kurtulan Türkiye'de bağımsızlığın önemli bir kısmını oluşturan ve siyasi bağımsızlığın anlamlılığını ve geçerliliğini koruyabilmesi için adım atılmasının gerekliliği savunulan diğer alan ise ekonomi olmuştur. Ekonomik bağımsızlık bir ulus devletin ayakta kalabilmesi ve siyasi varlığını koruyabilmesi için en önemli unsur olduğu gerekçesiyle 17 Şubat 1923 tarihinde İzmir'de İktisat Kongresi gerçekleştirilmiştir. İzmir İktisat Kongresi'nin düzenlenmesinde; Mustafa Kemal Atatürk, Mahmut Esat Bozkurt ve Kazım Karabekir etkili olmuştur (Atagenç, 2018: 74). Bu kongrede, o dönemde dünya genelinde etkisini hissettiren liberal iktisat anlayışına yönelik kararlar alınmıştır. Bu kararlardan bazıları aşağıdaki gibidir (Boratav, 2003, s. 37).

- "Yerli üretimin geliştirilmesine önem verilecektir"

- "Lüks İthalattan imtina edilecektir"

- Ekonomik gelişimi katkı sağlaması şartıyla yabancı sermaye yatırımlarına müsaade edilecektir"

- "Temettü vergisi yerini gelir vergisine birakacaktır"

- "Aşar vergisi kaldırılacak yerine daha uygun koşullu bir vergi getirilecektir"

- "Tütün tarımı ve ticareti serbest olacaktır, ihraç edilen tütünün işlenmiş olması gerekmektedir ve vergileri tüketiciden alınacaktır"

- "Tüm işgücüne sendika hakkı verilecektir".

Yukarıda 1923 yılında toplanan İzmir İktisat Kongresi'nde alınan bazı önemli kararlara yer verilmiştir. Söz konusu kararların ekonomik boyutu olduğu gibi mali boyutları da bulunmaktadır. İthal ikameci bir üretim anlayışının benimsenmesi, yerli üreticinin desteklenmesi ve korunması, yabancı sermaye akışına kontrollü bir biçimde müsaade edilmesi, üretimde ve ticarette "millileşme" nin ön plana çıkartılması ve teşvik edilmesi amaçlanmıştır. Vergi politikalarında adil ve dengeli bir dağılımın gözetilerek özellikle de tarım kesimi yani çiftçiler üzerindeki vergi yükünün hafifletilmesi Kongre'nin temel iktisadi ve mali konularını oluşturmuştur.

İzmir İktisat Kongresi sonucunda tarım kesimi üzerinden alınan ve devletin Osmanlı'dan beri en önemli gelir kaynağını oluşturan Aşar Vergisi 1925 yılında kaldırılmıştır. Yerine Kazanç Vergisi getirilmiş fakat Aşar Vergisinin sağladığı kamu kaynağını sağlamakta yetersiz kalmıştır. Aşar Vergisinin kaldırılmasıyla 1926 yılı bütçesi açık vermiş ve yeni kamu kaynağı arayışları devam etmiştir. Önce 1929 Dünya Ekonomik Buhranı'nın sonrasında ise 1939 
yılında başlayan II. Dünya Savaşı'nın ekonomik etkileri Türkiye'ye de yansımıştır (Coşar, 2004, s. 26). II. Dünya Savaşı'nın olumsuz ekonomik etkilerinin yanısıra Türkiye Cumhuriyeti Devleti bütçesinin o dönem dörtte birine denk gelen ve düzenli olarak ödenmesi zorululuğu bulunan Osmanlı' dan kalan diş borç ödemeleri ile birlikte savunma harcamalarının bütçe üzerinde oluşturduğu mali yük yeni kaynak arayışlarını ihtiyaç haline getirmiştir (Gökbunar, Arslan vd., 2016, s.232). Bu anlamda ekonomide azınlıkların hâkimiyetini k1rarak piyasayı "millileştirmek" ve yeni bir kamu kaynağı oluşturmak amaçlarıyla 12 Kasım 1942 yılında Resmi Gazete'de yayımlanan kanunla Varlık Vergisi uygulamasına geçilmiştir.

\section{Varlkk Vergisinin Mükellefleri ve Matrah Tesbiti}

Dünya'daki servet vergileri uygulamalarına bakıldığında, vergi tarifelerinde kademeli artış tarifelerinin diğer bir ifadeyle artan oranlı vergi tariflerinin uygulandığını tespit etmek mümkündür (Rudnick ve Gordon, 1996, s.2). OECD ülkeleri içinde Norveç'te 15.000 Euro civarındaki vergi matrahına \% 0.6 ile \% 1.1 arasında değişen vergi oranları uygulanmaktadır. Yine aynı ülkenin bütçesi incelendiğinde, servet vergilerinden elde edilen vergi gelirlerinin tüm vergi gelirleri içindeki oransal payının yaklaşık \% 1.15 civarında olduğu ölçümlenmiştir (Hansson, 2002, s. 3).

Varlık vergisinin mükellef gruplarının tayini ve ödenecek vergi miktarlarının tespiti için her il ve ilçede valiler ve kaymakamlar koordinatörlüğünde tespit komisyonlarının oluşturulması planlanmıştır. Böylelikle verginin yerel ekonominin gerçekliğine uygun olarak tespit edilmesi ile vergilendirmenin etkinliğinin sağlanabileceği düşünülmüştür. Oluşturulan tespit komisyonlarını belirlemiş oldukları mükellef grupları genel olarak müslim ve gayrimüslim ifade edilmişse de ayrıntılı hali aşağıdaki gibi oluşturulmuştur ve mükellef grupları grupların baş harfleri ile temsil edilmiştir (Akar, 2006, s. 2025).

- Müslüman Grubu (M)

1. Beyannameli Müslümanlar (BM)

2. Fevkalade Müslümlar (FM)

3. İratlı Müslümanlar (IM)

- Gayrimüslim Grubu (G)

1. Beyannameli Gayrimüslimler (BG) 
2. Fevkalade Gayrimüslimler (FG)

3. İratlı Gayrimüslimler (İG)

4. Hizmet Erbab1 (HE)

5. Seyyarlar (S)

6. Dönmeler (D)

Varlık vergisinin matrah takdirleri ve vergi tarhiyatları tamamen tahime dayalı olarak belirlenmiştir. Matrah tespitleri yapılırken özellikle karine usulünden yararlanılmıştır. Matrah tespit aşamasında güvenilir tüccarlar ve milli bankalardan mükellef gruplarına ilişkin bilgiler toplanmıştır. Matraha tespiti takdire dayalı olarak gerçekleştirilirken, bazı mükellef gruplarının matrahlarına uygulanan vergi oran ve miktarları ise şöyle belirlenmiştir (Mutlu, 2009, s. 51):

- Anonim şirketlerde herhangi bir mükellef grubu ayırımı yapılmaksızın tüm mükelleflerin 1941 safi kazancından, vergi ve zamlar çıkarıldıktan sonra kalan net tutarın yarısı kadar vergi tahsil edilmiştir.

- Fevkalade müslim grubunun vergisi II. Dünya Savaşı yıllarında elde ettikleri tahmin edilen kazançlar toplamının 1/8'i düzeyindedir.

- Fevkalade gayrimüslim grubunun vergisi II. Dünya Savaşı yıllarında elde ettikleri kazançlarının yarısı seviyesindedir. Ayrıca bu mükellef grubu için vergilendirmede üst sınır belirlenmiştir. Bu da bütün varlikları toplaminın yarısıdır.

- Müslümanların İratlılar ve fevkalade grubundakilerde de aynı şekilde savaş yıllarında elde ettikleri tahmin edilen kazançlar toplamının 1/8' $\mathrm{i}$ varlık vergisi olarak alınacaktır.

- Aile Anonim Şirketlerinde ve kollektif şirketlerde ortakların vergileri, müslim veya gayrimüslim olup olmadıklarına göre takdir edilecektir.

- Gayri safi irat üzerinden kazanç vergisi veren müslimlerin varlık vergisi 1941 yılı kazanç vergisi kadar alınacaktır.

- Büyük çiftçilerin vergisi, varlıklar toplamının \%5'i kadardır.

- Emlak sahibi gayrimüslimlerde fevkalade grupta olmayanların emlak gelirlerinin 1500 lirayı aşan kısmı varlık vergisi olarak alınacaktır.

- Gayrimenkul sahibi Müslüman grupta ise emlak gelirleri toplamı 3000 liraya kadar olanlar için vergi hesaplanmayacak yani 3000 lira istisna kabul edilecektir. Fevkalade Müslim grubuna girmeyen Müslümanlar için istisna tutarını aşan kısmı için \%25 oranında varlık vergisi hesaplanacaktır. 
- Seyyarlar genellikle 500 lira vergi alınacaktır.

- Aylık geliri 40 lira ile 50 lira arasındaki hizmet erbabı ise vergiden muaf olacaktır. Ev sanatları erbabı olan yalnız gayrimüslimlerden ise vergi istenecektir.

- Yahudiler ve dönmeler için gayrimüslim-müslim arası bir vergi tarifesi uygulanacaktir.

- Ticaretle uğraşan gayrimüslim grup için yıllık gayrisafi kazançları üzerinden yapılan faaliyet türüne göre $\% 20,25,30,35,40,45,50,60$, 100, 130 oranlarında vergi tarhiyatı gerçekleştirilecektir.

\section{Varlık Vergisinin Tahsili}

Varlık Vergisi'nin kanuni ödeme periyodu aylıktır. Söz konusu bir aylık dönemin ilk on beş günü verginin herhangi bir ceza yürütülmeden aslının tahisl edileceği dönemdir. Bu dönemden sonra gelen haftada yapılan ödemeler için vergi \%1 cezalı olarak, ikinci haftasında yapılan ödemelerde ise vergi \%2 cezalı olarak tahsil edilecektir (Ergeç, 2005, s. 33).

17 Aralık 1942 tarihinden itibaren il ve ilçe varlık vergisi tespit komisyonları tarafından mükellef grupları için hesaplanan vergi borçları listeler halinde ilan edilmiştir. Mükelleflerin büyük bölümü ise adlarına hesaplanan vergileri ilk on beş günlük sürede, verginin kaldırılacağı umuduyla ödememişlerdir. itibaren illerde varlık vergisi listeleri ilan edilmeye başlanmıştır. Tahsilâtın ilk günlerinde yükümlülerin büyük bir bölümü beklemeyi daha uygun görmüşler verginin haksızlıklarla dolu olduğunu ve bir an önce kaldırılacağı umudunu taşımışlardır. Resmi makamlardan yapılan açıklamalarda verginin cezasız ödeme süresinin uzatılmayacağı duyurulmuştur. Normal vergi ödeme döneminin son günlerinde vergi daireleri veznelerinde yoğunluk yaşanmış ve vezneler son gün gece yarısına kadar vergi tahsilatı ile uğraşmışlardır (Ökte, 1951, s. 69).

5 Ocak 1943 tarihinden itibaren normal ödeme süresinde vergisini ödemeyenlerin listeleri ilan edilmeye başlanmıştır. Vergi tahsilatının büyük çoğunluğu \%1 ve \%2 cezalı vergi tahsilatının yapılacağı dönemlerde gerçekleştirilmiştir. Hatta üç dönemden oluşan tahsilat periyodunda en çok vergi tahsilatı \%2 cezalı tahsilatın yapıldığı üçüncü dönemde elde edilmiştir. Varlık vergisinin toplam ödeme süresi diğer bir ifadeyle üçüncü ödeme döneminin sonunun 20 Ocak 1943 tarihi olduğu duyurulmuştur. Söz konusu tarihten sonra 
"Bedenen Çalıştırma Talimatnamesi" gereğince vergi ödemesini yapmayanlar için kamu işlerinde çalıştırılmak üzere bir taraftan sevk işleri yapılmaya başlanılmış, bir taraftan da "Tahsil-i Emval Kanunu"nu gereği haciz işlemleri yürütülmüştür (Zurcher, 2009, S. 42).

Varlık vergisinin tahsilat sonuçlarına bakıldığında müslimlerin gayrimüslimlere kıyasla tarh ve tahakkuk ettirilen verginin çoğunluğunu ödedikleri tespit edilmiştir. Diğer bir ifadeyle müslimlerin vergi gayretlerinin gayrimüslimlere göre daha yüksek olduğu söylenebilir. Bu sonucun ortaya çıkmasında müslimlerin gayrimüslimlere göre varlık vergisi yüklerinin daha az olmasının etkili olduğu ifade edilebilir.

\section{Varlık Vergisinin Kaldırılması}

Varlık Vergisine yönelik olarak ağır ve adil olmayan koşulları sebebiyle gerek iç çevrelerden gerekse de dış çevrelerden ağır eleştiriler yöneltilmiştir. Bu sebeple 12 Kasım 1942 tarihinde Resmi Gazete'de yayımlanarak yürürlüğe giren vergi, yaklaşık on altı ay uygulamada kaldıktan sonra 15 Mart 1944 tarihinde uygulamadan kaldırılmıştır. 4530 sayılı "Varlık Vergisi Bakayasının Terkinine Dair Kanun" çıkartılarak tüm mükelleflerin kalan vergi borçları terkin edilmiştir (Aksanyar ve Biçer, 2008, 10).

\section{Varlık Vergisinin Sosyo-Ekonomik Sonuçları}

Varlık Vergisi'nin özellikle gayrimüslim gruplar için yüksek oran ve miktarlar taşıması üzerine vergisinin hiç ödeyemeyen veya bir kısmını ödemede problem yaşayan mükellefler için bu kişilerin vergi borçlarının karşılığı olarak kamu işlerinde bedenen çalışmaları için Erzurum Aşkale'de kamplar oluşturuldu. Burada mükellefler zorunlu kamusal hizmetlerde bulunacaklardı. Bedenen çalışma mükellefiyeti sadece varlık vergisi borcu olan gayrimüslimlere getirilmişti.

Varlık vergisi borçları nedeniyle Aşkale'deki çalışma kamplarına gönderilecek olan mükelleflere günlük çalışmaları karşılığ1 250 kuruş verilecek bunun 60 kuruşu iaşe ve ibate gideri olarak kesilecek geriye kalan tutar ise varlık vergisi borçları için mahsup edilecekti (Aktar, 2002, s. 15). 
Aynı zamanda mal varlığı olan borçlu mükellefler için haciz işlemleri başlatılmıştı. Bu işlemler sona erinceye ve vergi borçları ödeninceye kadar gayrimenkul sahibi borçlu mükellefler de çalışma kampları için gözaltına alınmakta ve kamp yerlerine sevkiyatları gerçekleştirilmekteydi.

Mükellefiyet gruplarının çoğunluğu İstanbul'da olduğundan 1943 yılının Şubat ve Eylül ayları arasında toplamda 1869 gayrimüslim mükellef güvenlik güçlerince evlerinden toplanarak Sirkeci'de bulunan toplanma alanlarına götürülmüşlerdir. Bu mükelleflerin 1229'u buradan çalıştırılmak üzere Aşkale'ye sevk edilmişlerdir. Geriye kalan mükellefler ise vergi borçlarını nakit temin ederek Sirkeci'de beklerken veya Aşkale'ye yollandıktan sonra çalıştırılmalarına gerek kalmaksızın ödemişlerdir. Vergi borçlarını ödemek üzere Aşkale'ye gönderilen borçlulardan 21'i yaşlarından veya hastalıklarından dolayı çalışma kamplarında vefat etmiştir (Akar, 1999, s. 34).

Varlık vergisi uygulamasıyla özellikle de mükellefiyet gruplarının çoğunluğunun bulunduğu İstanbul'da, İstanbul'un değerli yerlerinde bulunan yüksek rayiç bedellere sahip olan gayrimüslimlere ait olan gayrimenkuller, vergi borçlanı nedeniyle gerek haciz yoluyla gerekse normal satışları yapılarak piyasa değerlerinin epey altında tutarlara satılmışlardır. Varlık vergisi'nin hedefinin mülkiyeti ve piyasayı millileştirmek ve yabancıların özellikle ticaretteki üstünlüğünü kırmak olduğu düşünülürse bu amaca büyük ölçüde ulaşıldığı söylenebilir.

Varlık vergisi uygulamasıyla birlikte mülkiyet yapısının ve piyasadaki sermaye üstünlüğünün yabancılardan Türklere doğru el değiştirmesiyle el değiştirmesi ile nüfus yoğunlukları gerçekleşen göçler sonucunda değişimler oldu. İllerin nüfus yoğunluklarında gözlemlenen değişim niceliksel olmaktan ziyade niteliksel olarak ortaya çıktı.

1944 yılında uygulamadan ve Türk vergi mevzuatından kaldırılan varlık vergisinin akabinde Türkiye demokrasinini güçlendirmek ve bir bakıma varlık vergisinin neden olduğu uluslararası prestij kaybını giderebilmek için 1946 yılında çok partili yaşama geçmiştir (Feroz, 1994, s. 17). Ekonomik açıdan 1929 Dünya Ekonomik Buhranı'nın yaşanmasından itibaren hem Dünya'da hem de Türkiye'de izlenen korumacı, dışa kapalı ve yerli üretimi ve üreticiyi destekleyen ekonomi politikalarında Türkiye'de 1946 yılı ile birlikte gevşemeler yaşanmaya başlanmıştır. Bu tarihten sonra özellikle de 1950'li yılların başı ile birlikte ithalatın arttığı, dış açık probleminin yaşandığı 
ve dış yardımların ve yabancı sermaye yatırımlarının arttığı bir dönemin başladığı söylenebilir. Bu liberalleşmeye yönelik yeni ekonomik sürecin başlangıç noktası 1945 yılında hazırlanan ve devletçi niteliği olan Beş Yıllık Sanayi Planının uygulamaya alınmaması olmuştur. Bu plan yerine madencilik, enerji, demir çelik ve demiryolu dışındaki sektörlerin özel kesime açılmasının amaçlandığı 1947 yılında “Türkiye Ekonomik Kalkınma Planı” uygulamaya alınmıştır (Boratav, 2003, s. 71).

\section{Tartışma ve Sonuç}

Devletler olağanüstü dönemlerde kendilerinden beklenen görevleri ve harcalamaları gerçekleştirebilmek için mevcut gelir kaynaklarının dışında finansman ihtiyac hissedebilmektedirler. Savaşlar, doğal afetler ve kriz dönemleri genellikle devletlerin yeni finansman arayışları söz konusu olabilmektedir. Böyle dönemlerde devletlerin borçlanmaları artış gösterebileceği gibi borçlanmak yerine öz finansman kaynağı olarak yeni vergi koymak veya mevcut vergilerin oran ve miktarların arttırmak da tercih edilebilmektedir. Her iki finansman şeklinin devlete farklı maliyetler yükleyebileceği unutulmamalıdır. Aynı zamanda böylesine bu dönemlerde halkın yeni bir vergiye veya mevcut verginin oran ve miktarlarının arttırılmasına karşı olabilecek tepkisi nispeten daha sinurlı olabilmektedir.

1929 yılında tüm etkisi tüm Dünya'yı saran Amerika kaynaklı Büyük İktisadi Kriz' in yaşanmasıyla birlikte liberal ekonomi politikaları yerini daha çok korumacı ekonomi politikalarına bırakmıştır. Daha bu büyük krizin getirmiş olduğu ağır ekonomik fatura tam anlamıyla ödenmeden 1939 yılında II. Dünya Savaşı başlamıştır. Bu savaşın başlamasıyla birlikte 1929 Krizinin etkileri gerekçesiyle 1931 yılında uygulamaya alınan İktisadi Buhran Vergisi gibi, 1942 yılında varlık vergisi yürürlüğe girmiştir. Temelde servet vergisi niteliği gösteren verginin mükellefleri varlık sahibi olan müslimler ve gayrimüslimler olmakla birlikte gayrimüslimlerin vergi oranları ve miktarları müslimlere göre daha fazla olmuştur.

Böyle olunca varlık vergisinin getiriliş nedeninin sadece II. Dünya Savaşı'nın getirdiği ekonomik tahribatı gidermek olduğu söylenemez. Görünürde nedeni bu olmakla birlikte varlık vergisinin esas getirilme amacı 1923 İzmir İktisat Kongresi'nde de ifade edildiği gibi piyasanın millileştirilmesi ol- 
muştur. Azınlıkları oluşturan gayrimüslim tebaanın Osmanlı'daki gibi Türkiye Cumhuriyeti Devleti'nde de mülkiyeti ve ticareti dolayısıyla piyasayı ellerinde bulundurmaları, bu alanların el değiştirerek "millileştirilmesi" fikrini ve amacını ön plana çkartmıştır.

Varlık vergisi uygulaması ile kısa dönemli olarak bu amaçlara ulaşılmışsa da vergi uygulanış biçimi nedeni ile ağır eleştirilere maruz kalmıştır. Bunlardan en önemlisi de vergilendirmenin temel ilkelerinden olan vergi adaletini sarsmış olmasıdır. Getirilen vergi ile gayrimüslim olanları yaptıkları ticari işlerden caydırabilmek adına yüksek vergi oranları ve miktarları uygulanmıştır. Vergi yükünün toplumun sadece belli kesimi üzerinde yoğunlaşmış olması vergi adaletinin ciddi anlamda sarsılmış olduğunun göstergesidir. Verginin asıl hedefinin azınlıklar olması ve vergisini ödeyemeyenlerin çalışma kamplarında bedenen çalıştırılmaları ve burada sınırlı da olsa ölümlerin yaşanmış olması İnsan Hakları açısından da uluslararası kamuoyunda tepkilerin oluşmasına neden olmuştur. Yine benzer şekilde vergilendirmenin konusu objektif olarak belirlenmeyerek sübjektif kriterler üzerinden hareket edilmiştir. Diğer bir ifadeyle verginin getirilmiş amacı mükelleflerin kazançları ve servetlerinin vergilendirilmesinden ziyade belli mükellef gruplarının vergilendirilmesi yani azınlıkların vergi yüklerinin arttırılması olmuştur. Vergi sistemlerine dönemi ve gerekçesi ne olursa olsun yeni bir vergi getirilmek istenildiğinde, vergi tekniğine ve vergilendirme ilkelerine uygun düzenlemelerin oluşturularak kanunlaştırılması ve uygulamaya alınması gerekmektedir. Verginin genellik, eşitlik ve adalet ilkelerine uygun olarak vergi kanunlarının tertibi ve tahsisi, toplumunun sosyolojik ve psikolojik olarak vergiye bakış açısını olumlu etkileyerek vergiye gönüllü uyum seviyesini arttırabilmekte ve dolayısıyla hazinenin vergi tahsilatı oranını iyileştirebilmektedir. Varlık vergisinin bu anlamda da vergi adaleti ilkesi temelli bir vergilendirme olmadığı söylenebilir. Nihayetinde verginin uygulanamazlığı ve gelen eleştiriler neticesinde 1944 yılında kaldırılmıştır.

$\mathrm{Bu}$ tarihten sonra gelişen konjonktürle birlikte ekonomi liberalleşmeye başlamıştır. Özellikle 1950'li yıllarla birlikte korumacı ekonomi anlayışı terk edilmiş, ithalat artmış, dış denge bozulmuş ve dış yardım ve yabancı sermaye yatırımları artmaya başlamıştır. Sonuç olarak varlık vergisi uygulaması ne vergilendirmenin etkinliği anlamında ne de sosyo-ekonomik sonuçları itibariyle bekleneni verememiştir. 


\section{EXTENDED ABSTRACT}

\section{Application of Assets Tax in Turkish Financial History and Evaluation of Socio-Economic Results \\ Mutlu Yoruldu \\ Balıkesir University}

When reviewing the financial history of the world, one can see that the extraordinary periods had positive or negative effects and reflections on many fields, particularly on political, social, economic and cultural fields. These extraordinary periods may occur because of natural disasters such as earthquakes, floods, epidemics, hurricanes as well as of war and conflicts between countries. One of the important results of extraordinary periods in terms of public finance is the changes in the tax systems and regulations of the countries. In countries that are experiencing such periods or that are being/have been affected by such periods, governments may find it legitimate to impose an additional tax on individuals in the community. It is obvious that governments have to make certain spending in order to compensate for the destructive and disruptive effects of extraordinary periods on markets. Based on this reality, governments can try to close their finance deficits by either adding a new tax to their tax systems, or expanding the base, increasing the rates or amounts of the existing taxes in the current system. In such periods when market distortions may occur, the reactions of people in the society to taxes can be relatively positive compared to a normal period. Although it is possible to add a new tax or increase the existing taxes in each tax type, it can be said that the taxes that are generally increased in extraordinary periods are wealth taxes. In these periods, there are various reasons for imposing taxes on wealth and wealth transfer, which can be seen as the primary tax resource. The most important thing is to realize the fiscal purpose of tax and another is to meet the tax revenue need by balancing and observing the social income distribution, which is the social purpose of tax. The taxes that are increased or newly introduced for the stated reasons may become permanent in the tax system of the country when the extraordinary period ends. There are examples in the word about this. What happened on 17 August 1999 in Turkey 
occurred in the Marmara Region and the devastating impact forming earthquake devastating effects on 26 November 1999 to eliminate the "solidarity tax" to be applied until the temporary tax status in 2003 for the purpose of the tax system has been added. The tax in question to eliminate the negative economic effects of the II. World War and to eliminate the wealth inequalities that emerged at the end of the war, it was applied in France in 1945 as an extraordinary tax for once. Afterwards, it was adapted to the Turkish tax system and turned into an ordinary tax resource with a permanent legal regulation made on November 18, 2005, under the name of "Special Communication Tax" since it was thought to provide and provide significant tax income.

The "wealth tax" in Turkish public finance history, which was put into force in 1942 in the extraordinary period of the World War II is an example of such taxes. Despite entering the military to World War II battle of negative economic effects of the deeply felt Turkey, said negative resolve economic impacts and the wealth tax to improve the uneven and unjust distribution of wealth in society tax was implemented as a result of intense debate. Although the purpose of introducing the wealth tax is aimed at meeting the financial, economic and social purposes of the tax, the differences and injustices in practice caused the wealth tax to be read and interpreted differently in terms of Turkish Financial History. Although the Wealth tax was a temporary wealth tax imposed on all taxpayers with subject of the tax, the differences in practice have caused the tax burden to concentrate on certain taxpayer groups with certain characteristics. The fact that the application of this tax, which brings many socio-economic discussions and results, had a disruptive effect on tax justice was one of the main discussions and its results. For this and similar reasons, the tax was repealed in 1944. The purpose of this study is to reveal and discuss the socio-economic consequences of the "wealth tax", which has an important place in Turkish financial history. Descriptive analysis technique, which is one of the qualitative research methods, and document scanning technique were used.

\section{Kaynakça / References}

Ahmad,F. (1994). Demokrasi sürecinde Türkiye 1945-1980. İstanbul: Hil Yayın. Akar, R. (1999). Aşkale yolcuları, varlık vergisi ve çalı̧ma kampları. İstanbul: Belge Yayınları. 
Akar, R. (2006). Tek parti dönemi: Varlık vergisinin ekonomik, toplumsal ve siyasi boyutları, Türkiye'de azınlık hakları sorunu: Vatandaşlık ve demokrasi eksenli bir yaklaşım- uluslararası konferans tebliğleri 9-10/12/2005. İstanbul: TESEV Yayınları.

Atagenç, İ. Ö. (2018). İzmir İktisat Kongresi ve 24 Ocak kararları sonrası Türkiye'nin liberal tecrübesinin karşılaştırmalı analizi. Gazi Üniversitesi İktisadi ve İdari Bilimler Fakültesi Dergisi, Gazi Akademi Genç Sosyal Bilimciler Sempozyumu 2017 Özel Sayısı, 74.

Aksanyar, N. ve Biçer, M. (2008). II. Dünya Savaşında çıkarılan varlık vergisinin Türk basınında ve kamu oyunda yansımaları. Dumlupınar Üniversitesi Sosyal Bilimler Dergisi, 21, 10.

Boratav, K. (2003). Türkiye Iktisat tarihi (1908-2002). Ankara: İmge Yayınevi.

Clark, E.C. (1984). Varlık vergisine yeniden bakış. İstanbul: Yapıt Yayınları.

Coşar, N. (2004). Kriz, savaş ve bütçe politikası (1926-1950). İstanbul: Bağlam Yayıncllik.

Drometer, M., Frank, M., vd., (2018). Wealth and inheritance taxation: an overview and country comparison. Ifo Dice Report, 2, 47.

Ergeç, D. (2005). Milli burjuvazi yaratılma sürecinde varlık vergisinin rolü. Maltepe Üniversitesi SBE Yüksek Lisans Tezi, İstanbul.

Gökbunar, R., Arslan, A., vd. (2016). Varlık vergisinin Türk romanında yansımaları. Bilig Dergisi, 78, 232.

Hansson, A. (2002). The wealth tax and economic growth. Lund University Conference Paper, 3.

Lewis, B. (1998). Modern Türkiye'nin doğuşu. Ankara: Türk Tarih Kurumu Basımevi.

Mutlu, A. (2009). Tanzimattan günümüze Türkiye'de vergileme zihniyetinin gelişimi. Ankara: Maliye Bakanlığı Strateji Geliştirme Daire Başkanlığı Yayınları.

Ökte, F. (1951). Varlık vergisi faciası. İstanbul: Nebioğlu Yayınevi.

Rudnick, R. S. ve Gordon, R. K. (1996). Taxation of wealth. Tax law design and drafting, 1, 2.

Thaçi, L. ve Gerxhaliu, A. (2018). Tax Structure and developing countries. European Journal of Economics and Business Studies, 4 (1), 214.

Zurcher, E. J. (2009). Modernleşen Türkiye'nin tarihi. İstanbul: İletişim Yayınları. 


\section{Kaynakça Bilgisi / Citation Information}

Yoruldu, M. (2020). Türk mali tarihinde varlık vergisi uygulaması ve sosyo-ekonomik sonuçlarının değerlendirilmesi. OPUS-Uluslararası Toplum Araştırmaları Dergisi, 16(29), 2300-2315. DOI: 10.26466/opus.735644 